Al Maal : Journal of Islamic Economics and Banking

http://jurnal.umt.ac.id/index.php/jieb

E-ISSN : $2580-3816$

Vol : 2 No. 1 Bulan Juli Tahun 2020

Hlm : $98-112$

DOI : 10.31000/almaal.v2i1.2803

\title{
Sertifikasi Halal dan Implikasinya Bagi Bisnis Produk Halal di Indonesia
}

\author{
Warto $^{1 *}$, Samsuri $^{2}$ \\ ${ }^{1,2}$ Prodi Perbankan Syariah, FAI Universitas Muhammadiyah Tangerang, Indonesia \\ *warto@umt.ac.id
}

\section{ABSTRACT}

This paper aims to determine the implications of halal certification for the halal product business in Indonesia. The issue of halal has become a global trend marked by the presence of halal certification institutions in various parts of the world. This paper uses descriptive qualitative methods through a review of relevant literature and observations of the practice of implementing halal guarantee systems in Indonesia. Data obtained through journals, books, magazines, newspapers, electronic media, such as the official website of LPPOM MUI and personal communication with competent sources. The results showed that the certification of halal products has positive implications in building a halal business climate in Indonesia. For consumers, halal certification provides protection, guarantees, product halal information and becomes an instrument of business ethics. For business people, halal certification provides benefits to increase consumer confidence and reach the global halal food market.

Keywords: Certification; Labeling; Products; Halal Business; Implications.

\begin{abstract}
ABSTRAK
Paper ini bertujuan untuk mengetahui implikasi sertifikasi halal bagi bisnis produk halal di Indonesia. Isu halal telah menjadi tren global yang ditandai dengan hadirnya lembaga-lembaga sertifikasi halal diberbagai belahan dunia. Paper ini menggunakan metode kualitatif deskriptif dengan melalui peninjauan pustaka yang relevan dan pengamatan praktik pelaksanaan sistem jaminan halal di Indonesia. Data diperoleh melalui jurnal, buku, majalah, koran, media elektronik, seperti website resmi LPPOM MUI dan komunikasi pribadi dengan narasumber yang kompeten. Hasil penelitian menunjukkan bahwa sertifikasi produk halal memiliki implikasi positif dalam membangun iklim bisnis halal di Indonesia. Bagi konsumen sertifikasi halal memberikan perlindungan, jaminan, informasi kehalalan produk dan menjadi instrumen etika bisnis. Bagi para pelaku usaha, sertifikasi halal memberikan keuntungan untuk meningkatkan kepercayaan konsumen dan meraih pasar pangan halal global.
\end{abstract}

Kata kunci : Sertifikasi; Labelisasi; Produk; Bisnis Halal; Implikasi. 


\section{Pendahuluan}

Pangan, obat-obatan, kosmetika dan produk guna pakai merupakan bagian dari kebutuhan hidup. Semua kebutuhan tersebut harus terpenuhi secara baik, cukup, aman, bermutu, dan bergizi. Dari aspek harga, produk kebutuhan juga harus terjangkau oleh daya beli masyarakat. Selain itu produk-produk kebutuhan tidak boleh bertentangan dengan agama, keyakinan, dan budaya masyarakat. Untuk memenuhi semua hal tersebut perlu adanya suatu sistem produksi yang memberikan jaminan dan perlindungan, baik bagi produsen maupun konsumen.

Di sisi lain, para pelaku usaha di bidang produk kebutuhan hidup juga harus memiliki rasa tanggung jawab terhadap produk-produk yang disebar-luaskan. Baik itu berkaitan dengan kesehatan maupun kehalalan produk. Masyarakat juga berhak mengetahui dan mendapatkan informasi yang jelas mengenai setiap komposisi produk yang disajikan sebelum membeli dan mengkonsumsi. Informasi tersebut terkait dengan asal bahan, keamanan, mutu, kandungan gizi, dan keterangan lain yang diperlukan sehingga masyarakat dapat mengambil keputusan berdasarkan informasi yang benar dan akurat. Akses informasi adalah bagian terpenting dalam memenuhi prinsip keterbukaan informasi bagi konsumen yang di dalamnya mengandung makna adanya kepastian hukum sebagaimana tujuan yang digariskan dalam penyelenggaraan perlindungan terhadap konsumen.

Kemajuan ilmu pengetahuan dan teknologi di bidang industri pengolahan produk telah berkembang dengan sangat cepat. Dengan memanfaatkan kemajuan ilmu pengetahuan dan teknologi, pengolahan produk kebutuhan hidup telah menggunakan berbagai bahan, baik yang berasal dari bahan halal maupun haram, baik disengaja maupun tidak disengaja. Adanya bahan tambahan produk dari berbagai bahan dasar terutama berupa ekstrasi dari bahan hewani telah mengakibatkan percampuran antara bahan halal dan yang tidak halal. Adanya percampuran bahan dalam produk mengakibatkan produk kebutuhan berubah menjadi tidak halal. Dengan adanya pemanfaatan bahan-bahan tidak halal dalam berbagai produk kebutuhan hidup maka produk-produk yang beredar di masyarakat belum terjamin kehalalannya meskipun pelaku usaha sudah menyatakan halal pada produk yang dipasarkan. Hal ini karena untuk mengetahui kehalalan dan kesucian suatu produk olahan diperlukan kajian dan pengetahuan khusus multidisiplin, seperti pengetahuan di bidang pangan, kimia, biokimia, teknik industri, biologi, farmasi, dan pemahaman tentang syariat.

Indonesia adalah negara yang memiliki penduduk muslim terbesar di dunia yang tentu saja berkepentingan dengan peredaran produk yang aman dan berstandar halal. Sebab secara otomatis kaum muslim menjadi konsumen terbesar di negeri ini di samping menjadi incaran dan target impor negara-negara lain. Maka itu sepatutnya konsumen dalam negeri mendapatkan perlindungan dalam memperoleh kepastian tentang kehalalan produk pangan yang beredar.

Kedudukan konsumen dihadapan para pelaku usaha pada umumnya memang sangat lemah. Konsumen menjadi objek dari aktivitas bisnis para pelaku usaha melalui promosi, iklan dan cara penjualan serta penerapan perjanjian-perjanjian standar yang acapkali secara sengaja merugikan konsumen. Lemahnya posisi konsumen menjadi sasaran empuk bagi para pebisnis yang acapkali mengelabuhi konsumen melalui produkproduk yang ditawarkan. Dengan proses peredaran produk yang cepat disinyalir para pebisnis memiliki ruang gerak yang bebas dalam memberikan produk yang tidak 
sepatutnya. Oleh karena itu, pemerintahan harus turun tangan memberikan perlindungan kepada masyarakat konsumen.

Produk berstandar halal sudah seharusnya menjadi bagian integral yang tak terpisahkan dari praktik perdagangan dan ekonomi global yang menuntut adanya standarstandar dan kualitas baku internasional untuk mendapatkan kepercayaan dari konsumen lintas negara. Dengan demikian aliran barang, jasa, modal, ilmu pengetahuan antar negara menjadi makin mudah. Perdagangan internasional berpengaruh sangat besar terhadap perekonomian antar negara tersebut yang dapat menciptakan iklim kondusif yang saling menguntungkan dari perdagangan timbal balik, bahkan lebih efesien dalam memproduksi dan memasarkan barang. Banyak pakar yang menyimpulkan bahwa manfaat perdagangan lintas negara melampaui manfaat persaingan militer dan perluasan wilayah.

Memenuhi kebutuhan hidup halal merupakan hak dasar bagi setiap muslim. Hal ini bukan saja berhubungan dengan keyakinan beragama, tetapi juga berkaitan dengan dimensi kesehatan, ekonomi, keamanan dan kebutuhan ibadah. Sebagai negara berpenduduk mayoritas muslim, tanpa diminta sudah semestinya negara hadir melindungi warganya dalam pemenuhan hak-hak mendasar warganya. Selaras dengan itu pelaku usaha (produsen) juga sudah seharusnya memberikan perlindungan kepada konsumen. Untuk kepentingan tersebut, maka dituntut peran yang lebih aktif negara dalam pengaturan sistem ekonomi yang dijabarkan dalam strategi yang dilakukan negara dalam menjalankan instrumen bisnis di antaranya melalui regulasi.

Di sisi lain, gaya hidup halal (halal lifestyle) belakangan ini menjadi trend yang mendunia, tidak hanya di negara-negara yang mayoritas berpenduduk muslim tetapi juga di negara berpenduduk mayoritas non muslim. Kesadaran pemenuhan kebutuhun halal meningkat di kancah global seiring dengan menggeliatnya wisata halal global yang tidak melulu terbatas pada sektor destinasi wisata yang berkait situs keislaman (religi) tetapi menyangkut pemenuhan kebutuhan-kebutuhan wisata itu sendiri. Perusahaan berskala multinational corporation saat ini telah menerapkan sistem halal, sebut saja seperti Japan Airlaines, Singapore AirLines, Qantas, Chatay Pacific (Hong Kong), America Airlines menyediakan menu halal (moslem meal). Gejala ini juga merambah negara Amerika, Australia, Jepang, Cina, India, dan negara-negara Amerika Latin. Khusus Jepang, negara ini memiliki perhatian sangat serius terhadap pengembangan tren halal, salah satu indikasinya dengan digelarnya Japan Halal Expo yang selalu ramai sehingga cukup berhasil menyedot perhatian dan minat pelbagai pihak. Japan Halal Expo adalah pameran berskala besar yang memuat produk halal buatan Jepang. Tercatat, saat ini sudah ada 350 restoran di Jepang yang telah menyediakan makanan halal, 54 di antaranya adalah restoran khusus makanan negara tersebut.

Menyediakan pangan halal dan aman adalah bisnis yang sangat prospektif, karena dengan melalui sertifikasi dan label halal dapat mengundang pelanggan loyal yang bukan saja diminati oleh muslim tetapi juga masyarakat non muslim. Sebaliknya bagi produsen yang tidak memberikan keterangan halal yang memasarkan produknya di negara seperti Indonesia yang berpenduduk mayoritas muslim, produknya kurang diminati sehingga merugikan pelaku usaha sendiri. Pangan halal bagi muslim itu terbukti berkualitas dan sangat baik untuk kesehatan tubuh manusia. Adanya sertifikasi-labelisasi halal bukan saja bertujuan memberi ketentraman batin pada umat Islam tetapi juga ketenangan berproduksi bagi pelaku usaha. Apalagi dalam konteks globalisasi ekonomi dan pasar global, sertifikasi-labelisasi halal pangan makin diperlukan. Oleh karenanya, mengapa 
industri halal ini memiliki peluang besar untuk ikut bersanding dalam memberikan pangan yang aman, bermutu, bergizi, dan sehat. Industri halal pun sudah banyak diterapkan di negara islam lainnya, dan ada beberapa negara non islam yang telah melaksanakan industri halal ini. Karena industri halal tak hanya diberikan kepada konsumen Islam, kepada non Islam pun bisa.

\section{KAJIAN LITERATUR Sertifikasi dan Labelisasi Halal}

Produk yang beredar di Indonesia sangat beraneka ragam baik produk lokal maupun produk impor dari luar negeri. Pada setiap produk tersebut perlu adanya penanda halal untuk memudahkan konsumen dalam memilih produk halal. Oleh karena itu perlu adanya sertifikasi dan labelisasi produk

dalam memberikan jaminan produk halal kepada masyarakat khususnya warga muslim (Afroniyati 2014). Sertifikasi dan labelisasi merupakan dua hal yang berbeda namun saling memiliki keterkaitan.

Sertifikasi halal adalah suatu proses untuk memperoleh sertifikat halal melalui beberapa tahap untuk membuktikan bahwa bahan, proses produksi dan Sistem Jaminan Halal (SJH) memenuhi standar LPPOM MUI. (LPPOM MUI 2008). Pasca Implementasi Undang-undang Jaminan Produk Halal Nomor 33 tahun 2014, Sertifikasi halal didefinisikan sebagai pengakuan kehalalan suatu produk yang dikeluarkan oleh BPJPH berdasarkan fatwa tertulis yang dikeluarkan oleh Majelis Ulama Indonesia. (Panji, 2017). Di Indonesia lembaga yang otoritatif melaksanakan Sertifikasi Halal sebelum berlakunya UU JPH yang dilaksanakan secara voluntary adalah Majelis Ulama Indonesia (MUI) yang secara teknis ditangani oleh Lembaga Pengkajian Pangan Obat-obatan, dan Kosmetika (LPPOM).

Labelisasi halal adalah pencantuman tulisan atau pernyataan halal pada kemasan produk untuk menunjukkan bahwa produk yang dimaksud berstatus sebagai produk halal. Kegiatan labelisasi halal dikelola oleh Badan Pengawas Obat dan Makanan (Badan POM). Undang - Undang No. 7 Tahun 1996 tentang Pangan yang merupakan ketentuan payung tentang pangan memuat kewajiban pencantuman label pada pangan yang dikemas minimal enam unsur, dimana unsur yang satunya adalah keterangan tentang halal. Keterangan atau label halal pada suatu produk dapat menjadi acuan bagi konsumen Muslim untuk memilih dan membeli produk tersebut. (Desi, 2018).

Sertifikasi produk halal merupakan serangkaian proses yang harus dilalui pelaku usaha baik perseorangan ataupun badan usaha berbentuk badan hukum atau bukan badan hukum untuk mendapatkan sertifikat halal. Sertifikat halal diperoleh melalui beberapa tahapan pemeriksaan untuk membuktikan bahwa bahan baku, proses produksi, dan sistem jaminan halal produk pada suatu perusahaan sudah sesuai dengan standar yang ditetapkan LPPOM MUI. (LPPOM MUI, 2008). Sertifikasi dilakukan dengan melakukan serangkaian pemeriksaan yang dilakukan oleh auditor yang kompeten dibidangnya untuk kemudian ditetapkan status kehalalannya. Apabila syarat-syarat halal terpenuhi, maka produsen bisa mendapatkan sertifikat halal untuk produknya. Sertifikat halal ini kemudian digunakan oleh produsen sebagai syarat untuk dapat mencantumkan label halal dan nomor registrasi halal pada kemasan produk. Label halal inilah yang biasanya digunakan oleh pelaku usaha dalam rangka memenuhi kewajiban mereka untuk memberikan informasi kepada konsumen mengenai kehalalan produknya. Label ini 
berfungsi untuk menunjukkan kepada konsumen bahwa produk tersebut merupakan produk berstatus halal. (Faridah, 2019)

Pasca berlakunya UU No.33 Tahun 2014 tentang Jaminan Produk Halal (UU JPH) dan PP No. 31 Tahun 2019 tentang JPH berimplikasi berubahnya sistem prosedur dan registrasi sertifikasi halal dari bersifat sukarela (voluntary) menjadi wajib (mandatory) mulai 17 Oktober 2019. Selain itu, UU JPH melahirkan badan baru bernama Badan Penyelenggara Jaminan Produk Halal (BPJPH) di bawah Kementerian Agama. UU JPH ini mengamanatkan terhitung 17 Oktober 2019, semua produk wajib bersertifikat halal oleh BPJPH. Sebelum PP JPH terbit, proses sertifikasi halal masih dilakukan oleh Majelis Ulama Indonesia (MUI). Namun setelah PP JPH terbit, maka kewenangan penerbitan sertifikasi halal berada sepenuhnya di BPJPH selaku leading sector jaminan produk halal.

Berdasarkan UU JPH 2014 dan PP 2019, BPJPH menggantikan peranan LPPOM MUI dalam proses sertifikasi halal namun perubahan tersebut tidak disertai kesiapan BPJPH sehingga berpotensi menghambat proses sertifikasi halal yang selama ini sudah berjalan. Untuk menghindari hal tersebut maka Menteri Agama mengeluarkan Keputusan Menteri Agama RI No. 982 tahun 2019 mengenai layanan sertifikasi halal. Isi keputusan tersebut menegaskan bahwa dalam menyelenggarkan pelayanan sertifikasi halal BPJPH akan bekerja sama dengan Majelis Ulama Indonesia (MUI) dalam hal penetapan fatwa kehalalan produk dan Lembaga Pengkajian Pangan, Obat-obatan, dan Kosmetik MUI (LPPOM-MUI) dalam hal pemeriksaan dan pengujian kehalalan produk. Berdasarkan KMA RI No. 982 tahun 2019 tentang layanan sertifikasi halal tersebut maka skema sertifikasi halal adalah sebagai berikut.

Gambar 1. Skema Alur Proses Sertifikasi Mandatory Sesuai KMA No. 982/2019

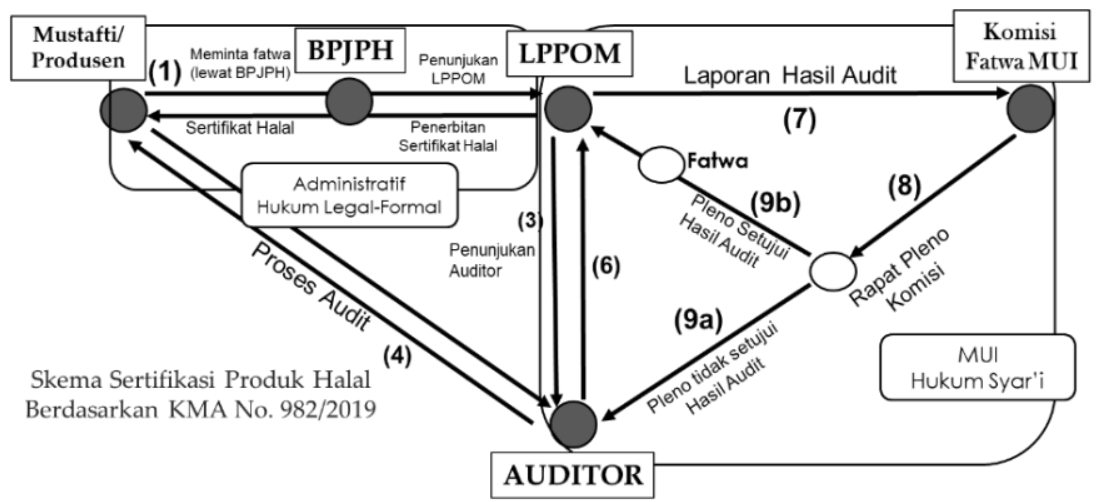

Sesuai keputusan Menteri Agama tentang Layanan Sertifikasi Halal ditetapkan bahwa BPJPH melayani produsen yang mengajukan permohonan sertifikat halal dan menerbitkan sertifikat halal. LPPOM MUI bertugas melakukan pemeriksaan dan pengujian kehalalan produk. Komisi Fatwa MUI bertugas melaksanakan pengkajian ilmiah terhadap hasil pemeriksaan dan pengujian kehalalan produk. Jika hasil audit tidak disetujui maka akan dilakukan perbaikan dan tindaklanjut pemeriksaan, jika disetujui Komisi Fatwa maka akan difatwakan sebagai produk halal. (KMA No. 982/2019).

\section{METODE PENELITIAN}

Penelitian ini menggunakan metode deskriptif kualitatif yang berlandaskan pada filsafat postpositivisme atau interpretatif. Metode ini digunakan untuk meneliti pada kondisi obyek alamiah, di mana peneliti sebagai instrumen yang valid. Teknik 
pengumpulan data dilakukan secara triangulasi, analisis data bersifat induktif, dan hasil penelitian kualitatif lebih menekankan makna daripada generalisasi. Penelitian ini termasuk jenis studi lapangan dan pustaka. Teknik yang digunakan untuk mengumpulkan data dalam penelitian ini meliputi 4 macam, yaitu dengan cara melakukan observasi, wawancara, dokumentasi dan triangulasi. Dalam penelitian ini keempat teknik pengumpulan data tersebut dipergunakan. Langkah observasi terstruktur dilakukan dalam penelitian ini sebab fokus penelitian telah ditentukan, yaitu bagaimana implikasi sertifikasi halal bagi bisnis produk halal di Indonesia. Observasi dalam penelitian ini dilakukan di MUI dan LPPOM MUI Pusat. Observasi bermanfaat untuk menemukan halhal yang tidak terungkap melalui dokumen. Wawancara dilakukan dengan beberapa pihak terkait di Komisi Fatwa MUI dan LPPOM MUI. Pengumpulan data berupa dokumentasi yang dimaksud dalam penelitian ini adalah berupa catatan peristiwa yang sudah berlalu, gambar, tulisan, atau karya dari seseorang. Dokumen dalam bentuk tulisan bisa berupa catatan harian, jurnal, buku, majalah, kebijakan dan peraturan.

\section{Hasil dan PEMbahasan \\ Manfaat Sertifikasi Halal Terhadap Bisnis Halal}

Sertifikasi halal merupakan tanda bukti bahwa produk yang diperjualbelikan telah memenuhi syarat kehalalan yang ditetapkan oleh fatwa MUI. Meningkatnya populasi kelas menengah di Indonesia menjadi salah satu potensi pemasaran yang sangat besar. Terutama kaum muslim yang mencapai $87 \%$ dari total penduduk dalam negeri. Secara bertahap, beberapa produsen barang mulai mengarahkan pemasaran khusus menyasar muslim kelas menengah, dan tak segan memberikan jaminan halal melalui sertifikasi halal. Dengan demikian, sertifikasi halal memberikan manfaat yang besar bagi konsumen, produsen, maupun pemerintah. Beberapa manfaat tersebut di antaranya sebagai berikut.

\section{Sertifikat Halal Menjamin Keamanan Produk yang Dikonsumsi}

Untuk mendapatkan sertifikat halal harus melalui tahapan yang ketat, dimulai dari awal produk tersebut diproduksi hingga produk tersebut terjual, itu semua tidak terlepas dari penilaian untuk sampai mendapatkan sertifikasi halal. Prosedur sertifikasi halal yang ketat, membuat kita menyakini bahwa produk atau barang kita terjamin kehalalannya dan untuk dikonsumsi atau dipakai. Dengan memiliki sertifikasi halal yang dikeluarkan oleh lembaga yang terpecaya, tentunya ini meningkatkan keamanan dan kepercayaan masyarakat akan produk tersebut.

Sistem jaminan halal mempersyaratkan bahwa proses produksi harus menerapkan cara produksi yang halal dan thayyib, artinya benar dan baik sejak dari penyediaan bahan baku sampai siap dikonsumsi oleh konsumen. Untuk memastikan itu, maka bahan baku harus aman dari cemaran biologis, kimiawi, fisikawi, dan bahan haram. (Sulistiyo, 2016). Proses produksi harus menggunakan alat dan tempat yang bersih dan higienis serta terhindar dari najis. Demikian juga penggunaan bahan tambahan dan penolong dalam produksi harus sesuai dengan ketentuan yang membolehkannya. Di industri besar implementasi Sistem Jaminan Halal juga sering digabung dengan sistem HACCP dengan menambahkan item haram sebagai komponen hazard yang harus diwaspadai. Dengan penerapan $\mathrm{SJH}$, maka produsen dipastikan hanya akan menghasilkan produk yang aman (halal dan thayyib) untuk dikonsumsi oleh konsumen. 


\section{Sertifikat Halal Memiliki Unique Selling Point (USP)}

Unique Selling Point atau Unique Selling Proposition merupakan salah satu konsep pemasaran yang membedakan satu produk dengan produk lainnya Melalui sertifikasi halal suatu produk memiliki USP yang tinggi. Dengan kata lain, produk bersertifikat halal memiliki keuntungan kompetitif sehingga membuat produk menjadi lebih bernilai di mata konsumen. Produk yang sudah memiliki logo halal pada kemasannya memiliki Unique Selling Point sebagai strategi penjualan yang unik dan memiliki citra positif di mata para konsumen.

\section{Sertifikat Halal Memberikan Ketenteraman Batin Bagi Masyarakat}

Sertifikasi halal memberikan ketenteraman dan keamanan lahir dan batin bagi konsumen. Bagi masyarakat yang menyadari pentingnya produk halal akan merasa waswas ketika menjumpai produk yang akan dibeli belum ada logo halal yang disahkan MUI, karena mereka yakin bahwa tanda kehalalan merupakan hal penting bagi suatu produk agar aman dikonsumsi atau digunakan. Dalam skala lokal, tidak jarang kasus bakso yang menggunakan daging babi, celeng, kucing, tikus, dan sebagainya bisa diredam dengan penerapan sistem jaminan halal (Prasetya 2015). Isu ini akan lebih berat jika pemilik usahanya adalah nonmuslim. Banyak kejadian bahwa pemohon sertifikat halal yang nonmuslim akan lebih bersungguh-sungguh dalam mengupayakan sistem jaminan halal (Sumarsongko 2016). Dengan fakta-fakta tersebut, sertifikasi halal terbukti mampu membantu pemerintah menjaga kestabilan sosial ekonomi.

Dengan adanya sertifikasi halal konsumen tidak perlu khawatir lagi dengan makanan yang mengandung sesuatu yang haram seperti mengandung babi atau hal haram lainnya karena produk yang dikonsumsi sudah mengantongi sertifikasi halal sehingga sudah pasti terjamin kehalalannya. Sertifikasi halal menjadi jaminan ketika konsumen akan membeli suatu produk, baik itu makanan, minuman, kosmetik, obat-obatan dan lainnya. Semua produk yang melalui proses sertifikasi halal, telah melewati berbagai standard yang didesain untuk memberikan perlindungan kepada konsumen. (Sulistiyo, 2016).

\section{Sertifikat Halal Memberi Keunggulan Komparatif}

Meskipun istilah halal sekarang ini tidak lagi menjadi isu agama semata dan sudah berkembang menjadi bahasa perdagangan global, namun nilai-nilai halal sesungguhnya melingkupi makna yang suci, bersih, murni, etika kerja, tanggung jawab, dan kejujuran. Produk halal bahkan telah memunculkan nilai memenuhi aspek hukum syariah, aman, bergizi, sehat, perikemanusiaan, pantas, dan ramah lingkungan (Evans dan Evans 2012).

Fungsi utama label halal adalah membantu konsumen memilih produk tanpa keraguan. Umumnya, setiap muslim akan melihat produk dengan label halal adalah jaminan aman untuk dikonsumsi. Dengan jaminan ini, maka pasar tidak hanya terbatas di dalam negeri, namun pangsa pasar muslim di luar negeri yang sangat luas menjadi terbuka lebar. Dengan kata lain halal dapat digunakan sebagai alat dan strategi pemasaran global (Evans dan Evans 2012).

\section{Sertifikat Halal Memberikan Perlindungan Terhadap Produk Dalam Negeri dari Persaingan Global}

Memasuki era pasar bebas, Indonesia dipastikan menjadi pasar yang paling menjanjikan. Jumlah penduduk dan wilayah geografis yang membentang dari Sabang 
sampai Merauke sudah pasti akan memerlukan berbagai kebutuhan konsumsi. Pasar ini menjadi kekuatan luar biasa jika dapat dipenuhi oleh produk-produk lokal. Namun, jika produk lokal tidak mampu memberikan jaminan kualitas maka produk luar negeri yang sejenis akan segera mengambil alih pasar tersebut. Salah satu contoh adalah produk daging ayam. Kewajiban sertifikasi halal produk asal hewan untuk masuk Indonesia sedikit banyak dapat meredam banjirnya daging impor (Putra 2014). Kasus impor paha ayam dari Amerika yang tidak dapat masuk ke Indonesia karena tidak disertai jaminan kehalalan sempat menjadi alat pelindung bagi peternak ayam lokal. Dengan selisih harga yang sangat jauh, maka impor paha ayam tersebut dapat mematikan ribuan usaha peternak ayam lokal.

\section{Sertifikat Halal Menghadirkan Sistem Dokumentasi dan Administrasi Perusahaan Yang Lebih Baik}

Kelemahan industri kecil dan menengah berbasis hasil pertanian terutama adalah masalah administrasi dan manajemen usaha. Usaha yang bermula dari usaha sampingan rumah tangga seringkali menerapkan pola pengelolaan rumah tangga yang tidak tercatat rapi. Dengan kondisi ini seringkali tidak ada pengarsipan dan ketertelusuran dokumen jika diperlukan. Penerapan sistem jaminan halal mempersyaratkan adanya penerapan sistem dokumentasi sehingga pelaku usaha dapat terbantu meningkatkan pengelolaan usaha dengan penerapan prinsip-prinsip manajemen yang moderen. (Sulistyo, 2016)

\section{Sertifikasi Halal Menjadi Tiket Untuk Mendapat Akses Pasar Global}

Produk yang memiliki sertifikasi halal akan memiliki kesempatan untuk memasarkan produknya di Negara muslim lainnya selain Indonesia, contohnya Malaysia. Selain bersaing dengan produk dalam negeri, produk-produk halal Indonesia juga dapat bersaing dengan produk luar negeri karena tidak semua produk luar negeri sudah memiliki logo halal. Sebagai contoh coklat atau oleh-oleh dari luar negeri. Walaupun tidak terindikasi memiliki kandungan babi atau hewan haram lainnya tetapi konsumen muslim tidak tahu bagaimana cara pembuatan atau pengolahannya.

\section{Implikasi Sertifikasi Produk Halal Bagi Bisnis Halal di Indonesia}

Pemberlakuan sertifikasi halal memberikan implikasi yang besar terhadap bisnis produk halal di Indonesia. Bisnis halal secara khusus di Indonesia menjadi obyek yang sangat menarik karena Indonesia adalah negara dengan penduduk Muslim terbesar di dunia. Keadaan inilah yang menjadikan Indonesia mempunyai potensi yang sangat besar dalam industri pengembangan produk halal di dunia. Karena jumlah penduduk Muslim terbesar dunia, maka pasar utama Indonesia adalah negeri sendiri.

Sebagai negara mayoritas beragama muslim, Indonesia berpeluang menjadi pusat ekonomi halal terbesar di dunia. Publikasi yang dilakukan oleh Badan Pusat Statistik Indonesia menyatakan bahwa penduduk Indonesia tahun 2010 mencapai 237,6 juta jiwa, dengan jumlah penduduk muslim sebanyak 207.176.162 jiwa, atau 87,18\% dari total keseluruhan penduduk Indonesia. Pada tahun 2017 jumlah penduduk Indonesia mencapai 261,9 juta jiwa. (BPS, 2010). Jumlah ini bertambah ada tahun 2019 mencapai 269,6 juta jiwa. Angka tersebut menunjukkan pertumbuhan yang sangat pesat apabila dibandingkan dengan tahun 2010. (Faqiatul, 2018). Dengan demikian, dalam kurun waktu 7 tahun, ratarata petumbuhan penduduk muslim Indonesia dalam periode 2010-2017 mencapai $1,27 \%-1.46 \%$ per tahun. Pertumbuhan penduduk muslim yang pesat secara linier mempengaruhi pertumbuhan permintaan akan produk halal. Ini dapat dilihat dari 
permintaan produk halal. Besarnya penganut agama Islam wajar membuat pemerintah mengeluarkan UU No. 33 tahun 2014 tentang Jaminan Produk Halal guna melindungi kepentingan konsumen yang berhak memakai produk yang sesuai syariat Islam, baik dari segi bahan pembuat, proses pembuatan hingga tahap pembungkusannya.

Indonesia memiliki konsumen muslim terbesar di dunia. Sedikitnya, 87 persen dari sekitar 260 juta umat muslim ada di Indonesia yang membutuhkan jaminan keamanan, kenyamanan, perlindungan, dan kepastian hukum mengenai kehalalan produk yang dikonsumsi maupun yang digunakan atau dimanfaatkan. Sebagai negara dengan penduduk muslim terbesar, Indonesia tentu menyediakan pasar yang sangat besar untuk produk-produk halal.

Indonesia merupakan negara yang memiliki keunggulan komparatif sebagai negara agraris dan maritim yang menjadi potensi perekonomian yang sangat besar untuk dikembangkan menjadi kegiatan bernilai tambah. Produk-produk halal memiliki tingkat pertumbuhan rata-rata tujuh persen per tahun, serta tumbuhnya kesadaran konsumen muslim terhadap produk-produk halal dan meningkatnya jumlah penduduk muslim yang mencapai 1,8 milliar jiwa dari 6 milliar jiwa penduduk dunia. Dengan perkembangan di atas, produsen dan pelaku bisnis halal telah memiliki rencana ekspansi pasar secara internasional, termasuk untuk ekspansi pasar produk halal Indonesia. (Purnomo, 2011)

Selain itu, Indonesia merupakan negara Konsumsi Halal Food Peringkat 1 di dunia. (Thomson Reuters, 2018). Berdasarkan catatan Global Islamic Economy Report 2018/2020, belanja penduduk muslim global pada produk dan jasa sektor ekonomi halal mencapai lebih dari USD 2,2 triliun pada tahun 2018. Indonesia menempati peringkat pertama sebagai konsumen terbesar produk halal pada sektor makanan dan minuman, yaitu dengan jumlah pengeluaran sektor sebesar USD 170 miliar. (Shahbandeh, 2019).

Gambar 2. Muslim Consumer Expenditure 2017

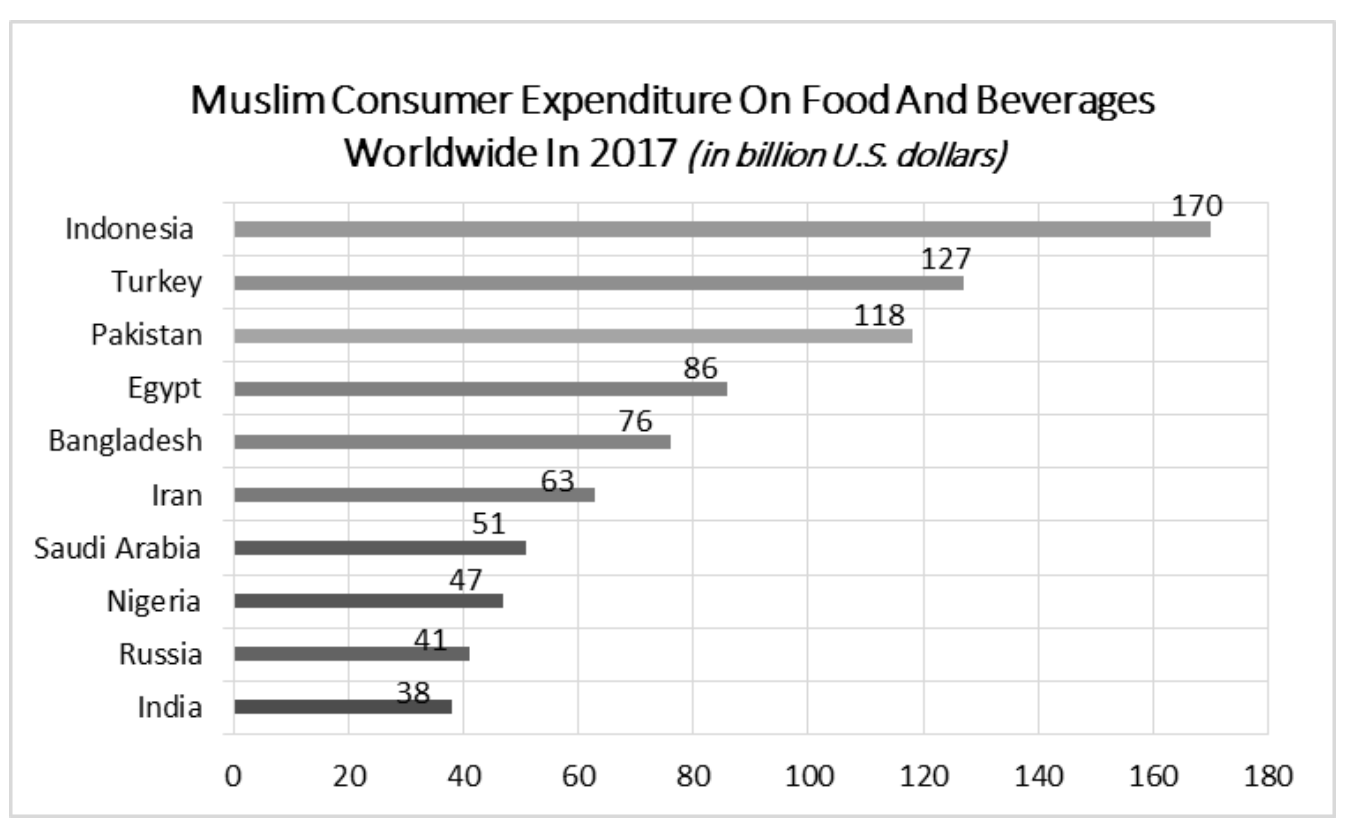

Sumber: Data State of the Global Islamic Economy Report 2017/2018 
Sebagai negara dengan mayoritas penduduk muslim, Indonesia memiliki kepentingan untuk meningkatkan ekspor non migas. (Warta Ekspor, 2015). Untuk itu Indonesia telah menyiapkan perangkat hukum melalui Undang Undang No. 33 tahun 2014 tentang Jaminan Produk Halal yang esensinya mengatur kehalalan suatu produk guna melindungi kepentingan konsumen domestik terhadap barang impor yang sudah teruji kehalalannya serta mengamankan ekspor produk komoditas agar dapat diterima terutama ke negara negara Timur Tengah dan OKI. (Handoyo, 2016).

Produk halal Indonesia memiliki peluang besar, untuk dapat bersaing dengan negara lain. Para pelaku usaha, baik produsen maupun eksportir Indonesia, yang telah mengantongi sertifikat halal maka produk-produk mereka akan lebih mudah diterima oleh konsumen produk halal di negara lain hanya dengan melihat label halal yang tercantum pada produk mereka. Sebagai contoh, jika seorang konsumen produk halal di negara lain yang ingin membeli makanan kalengan dan terdapat dua pilihan makanan kaleng yang sejenis, maka konsumen tersebut akan cenderung memilih produk yang telah mencantumkan label halal karena mereka merasa mendapat jaminan bahwa produk yang akan dikonsumsinya benar-benar halal dan baik. Untuk daging hewan misalnya, penyembelihannya dilakukan dengan memotong leher hewan tersebut dengan tujuan mengambil dagingnya. Penyembelihan secara Islam diartikan sebagai penyembelihan sesuai syariat Islam. Daging yang dihasilkan dari penyembelihan secara Islam menghasilkan daging yang kaya rasa, lembut, aman dan higienis. Hal ini lah yang membuat selain konsumen muslim pun menjadi tertarik akan produk dengan jaminan halal. (Warta Ekspor, 2015).

Peluang besar bisnis halal ini tentu harus diimbangi dengan peningkatan jumlah produk tersertifikasi halal. Mengutip data Badan Standardisasi Nasional (BSN), sertifikasi halal di Indonesia baru mencapai kurang dari 20 persen. (Lukihardianti, 2017). Hal ini sedikit berbeda dengan data yang dirilis oleh Direktorat Jenderal Bimbingan Masyarakat Islam yang menyebutkan bahwa total persentase produk bersertifikat halal sejak tahun 2011 sampai dengan 2014 adalah 26,11\% sehingga produk pangan, kosmetika, dan obat-obatan yang beredar dan belum bersertifikat halal tahun 2011-2014 sebesar 73,89\%. (Bimas, 2019). Jumlah produk tersetifikasi mengalami peningkatan signifikan sejak tahun 2012 -2019, dari jumlah 5.829 perusahaan meningkat tajam menjadi 13.951 perusahaan sehingga jumlah total perusahaan tersertifikasi halal sebanyak 73.902 perusahaan. Kenaikan jumlah sertifikasi halal tertinggi terjadi antara tahun 20172018. Pada tahun 2017, LPPOM MUI menerbitkan sertifikat halal sebanyak 8.157 unit dengan total 127.286 jenis produk. Sedangkan pada tahun 2018, LPPOM MUI menerbitkan sertifikat halal sebanyak 17.398 dari 204.222 jenis produk. Sehingga antara tahun 2017-2018 telah terjadi peningkatan penerbitan sertifikasi halal sebesar $114 \%$, angka tersebut menunjukkan bahwa perusahaan-perusahaan yang menjual produknya di Indonesia merasa bahwa pelabelan halal merupakan nilai tambah tersendiri untuk mendorong daya serap produk mereka di pasar. (Kusnadi, 2019). Jumlah ini terus bertambah di tahun 2019. Hal ini terlihat dari jumlah perusahaan yang melakukan sertifikasi halal bertambah dari 11,249 perusahaan pada tahun 2018, menjadi 13, 951 perusahaan, 15.495 sertifikat halal, dan 274.796 jumlah produk sehingga jumlah total sampai tahun 2019 sertifikasi halal MUI telah mencapai jumlah 73.902 perusahaan, 85.480 jumlah sertifikat halal dan 1.002.413 jumlah produk. (halalmui, 2019). 
Tabel 1. Data Sertifikasi Halal LPPOM MUI Periode 2012-2019

\begin{tabular}{cccc}
\hline Tahun & $\begin{array}{c}\text { Jumlah } \\
\text { Perusahaan }\end{array}$ & $\begin{array}{c}\text { Jumlah Sertifikat } \\
\text { Halal }\end{array}$ & $\begin{array}{c}\text { Jumlah Produk } \\
\text { Halal }\end{array}$ \\
\hline 2011 & 4325 & 4869 & 39002 \\
2012 & 5829 & 6157 & 32890 \\
2013 & 6666 & 7014 & 64121 \\
2014 & 10180 & 10322 & 68576 \\
2015 & 7940 & 8676 & 77256 \\
2016 & 6564 & 7392 & 114264 \\
2017 & 7198 & 8157 & 127286 \\
2018 & 11249 & 17398 & 204222 \\
2019 & 13951 & 15495 & 274796 \\
\hline JUMLAH TOTAL & 73902 & 85480 & 1002413 \\
\hline
\end{tabular}

Kehalalan sebuah produk yang dipasarkan sedianya memiliki peluang secara ekonomis. Hadirnya UU No.33 Tahun 2014 tentang Jaminan Produk Halal menjadi payung hukum bagi negara dalam penyelenggaraan jaminan produk halal. Jaminan produk halal diselenggarakan oleh Negara memiliki implikasinya tidak sederhana. Oleh karena itu, perlu disikapi secara serius oleh berbagai pihak terkait, khususnya kalangan muslim yang memerlukan kepastian hukum terhadap produk yang dikonsumsinya. Umat Islam perlu kepastian hukum terhadap produk yang dikonsumsi. Ada kebutuhan jaminan atas kehalalan produk. Produsen wajib menyiapkan informasi yang benar soal halal dan Negara wajib melayani.

Kebijakan sertifikasi halal memiliki manfaat ekonomis dan sangat strategis untuk mengoptimalkan captive market. Penerapan kewajiban sertifikasi halal bagi pelaku usaha dengan mengantongi sertifikasi halal produk yang dijajakan tanpa disadari berdampak positif terhadap perkembangan perekonomian di Indonesia. Dalam perspektif makro, kehalalan sebuah produk tetap menjadi tren di banyak negara di dunia. Apalagi, dengan jumlah penduduk muslim di Indonesia yang mencapai $87 \%$ dari total penduduk, potensinya amatlah besar. Harus ada kesadaran bersama tentang pentingnya mengoptimalkan captive market yang ada di depan mata, agar jangan sampai justru malah pihak luar yang memanfaatkan peluang ini. Dan produk halal bisa didorong ke arah sana.

Implikasi positif lainnya dari mandatori halal adalah terbukanya lapangan kerja baru. Sebab, dengan kewajiban bersertifikat halal, maka kebutuhan SDM pendukung terlaksananya jaminan produk halal (JPH) tentu jumlahnya besar. Di antaranya adalah kebutuhan auditor halal yang merupakan unsur penting dan harus ada dalam LPH (Lembaga Pemeriksa Halal). Auditor halal nantinya akan menjadi profesi yang cukup menarik. Hal ini tentu ini akan menjadi positif bagi perkembangan halal di Indonesia dan dunia.

Sertifikasi halal juga bisa menaikkan pamor ekspor karena saat ini lembaga tersebut sudah terakreditasi ISO dan bekerja sama dengan negara-negara muslim lain. Hal ini bisa memudahkan produk yang mengantongi sertifikasi halal berperan di perdagangan global. Target penjualan produk bersertifikat halal harus di ekspor ke luar negeri. Hal tersebut dapat dilakukan dengan cara memperbanyak akses dan kerja sama dengan negara OKI dan Timur Tengah. Satu keuntungan bagi para pengusaha Indonesia adalah bahwa 
Sistem Jaminan Halal MUI telah diadopsi oleh hampir seluruh Lembaga Halal di dunia, mulai dari Asia, Australia, Eropa, hingga Amerika dan Afrika. Jadi sertifikasi halal Indonesia sudah bisa diterima di banyak Negara.

Menurut Ketua Komite Tetap Timur Tengah dan Organisasi Kerja sama Islam (OKI) Kamar Dagang dan Industri, Fachry Thaib, isu halal adalah salah satu tantangan produk asal Indonesia sebagai negara dengan penduduk muslim terbesar di dunia. Saat ini ekspor Indonesia ke Timur Tengah berada pada kisaran 4,8 persen dari total ekspor nasional. Angka ini tentu akan naik signifikan jika semua produk Indonesia sudah bersertifikasi halal. Wakil Ketua Kamar Dagang dan Industri (Kadin) Komite Timur Tengah dan OKI Mohammad Bawazeer mengatakan bahwa ada kesempatan yang harus dimanfaatkan oleh para pengusaha Indonesia untuk bisa masuk ke pasar negara muslim. Yaitu kerja sama antara Kadin Indonesia sudah bekerja sama dengan Islamic Chamber of Commerce, Industry and Agriculture yaitu Kamar Dagang Dan Industri Pertanian di bawah OKI. Proses sertifikasi halal oleh negara-negara anggota Organisasi Konferensi Islam (OKI) dikoordinasikan oleh lembaga ini. Produk yang lolos sertifikasi halal pada negara yang bekerjasama dengan ICCIA, akan lebih mudah masuk ke negara tujuan. (Subagyo, 2019)

Sertifikat halal sangat dibutuhkan oleh produsen agar produknya mampu menembus pasar global terutama ke kawasan negara muslim Timur Tengah. Sebelum taken kontrak jual beli para importir dari kawasan Timur Tengah selalu menanyakan aspek kehalalan produk yang dibuktikan dengan sertifikat halal. Untuk keperluan pemasaran produk tersebut, selain telah memperoleh akreditasi SNI ISO/IEC 17065: 2012, LPPOM MUI telah terakreditasi The United Arab Emirates Scheme (UEA.S 2055.2) for Halal Product dan memperoleh sertifikat Emirates Autorithy for Standardization Metrology (ESMA). Berdasarkan sertifikat tersebut produk halal Indonesia diterima di Timur Tengah.

Selain itu, tingginya potensi ekonomi Islam, pada tahun 2023 diprediksikan akan mencapai 3 triliun dollar atau sekitar Rp 45.000 triliun. Tingginya potensi tersebut akan menjadi peluang bisnis halal yang besar bagi Indonesia. Menurut data Indikator Global Ekonomi Islam 2018-2019, saat ini Indonesia masih berada di posisi 10 dalam peringkat ekonomi syariah dunia. Menurut data yang sama, di tahun 2017, masyarakat Indonesia mencatatkan pengeluaran sebesar US \$218.8 miliar (di atas Rp 3.000 triliun) pada sektor ekonomi Islam.

Gambar 3. Indikator global Ekonomi Islam 2018-2019

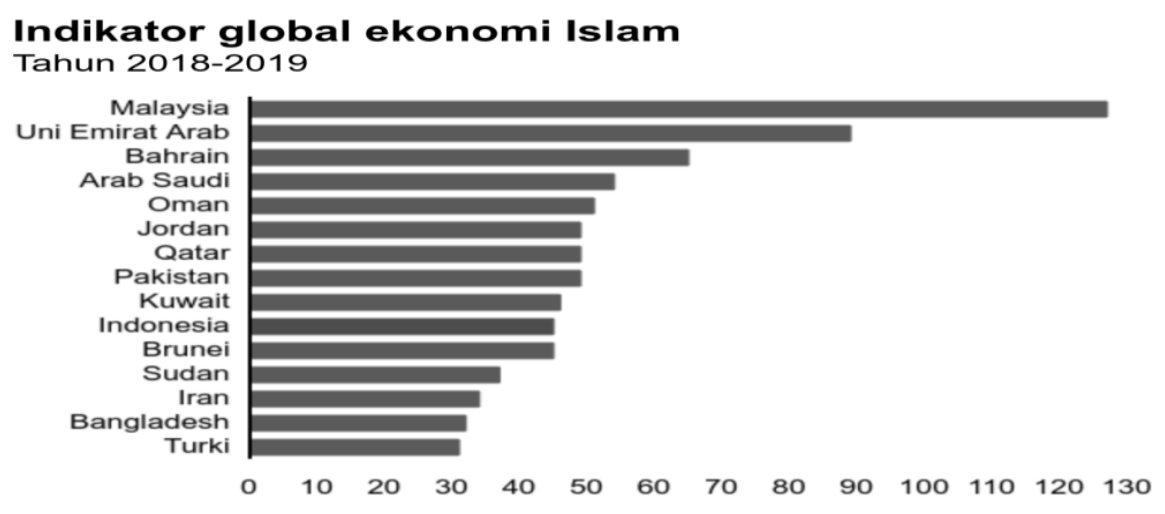

Sumber: State of the Global Islamic Economy, Thomson Reuters 
Potensi besar bisnis halal akan menjadi sebuah step untuk Indonesia memasarkan produk-produknya. Sehingga Indonesia tidak hanya menjadi negara konsumen terbesar produk halal global, tetapi juga menjadi produsen terbesar. Regulasi yang mewajibkan sertifikat halal akan mendukung eskpor produk Indonesia.

Gambar 4. Perbandingan Skor Antarsektor Halal tahun 2014-2018

Perbandingan Skor Antarsektor Halal di Indonesia Tahun 2014-2018 Sumber: Global Islamic Economy Gateway (2018)



Sumber: Masterplan Ekonomi Syariah Indonesia 2019-2024

Salah satu pasar potensial yang ingin ditembus pemerintah Indonesia adalah Timur Tengah, utamanya Arab Saudi, mengingat saat musim haji saja lebih dari 200.000 WNI berada di sana. Jika dihitung dari pemenuhan kebutuhan haji, ekspor halal Indonesia ke Arab Saudi dan Timur Tengah bisa tumbuh sebesar lima persen

\section{KESIMPULAN}

Menjadikan Indonesia sebagai pusat industri halal dunia bukanlah sesuatu hal yang mustahil, bahkan Indonesia memiliki peluang yang sangat besar untuk mendapatkannya, yaitu melalui instrumen sertifikasi halal yang didukung oleh UU JPH. Beberapa indikator telah terpenuhi bahwa Indonesia memiliki jumlah penduduk muslim yang sangat besar sekitar 260 juta jiwa atau sekitar $87 \%$ dari total penduduk Indonesia. Jumlah ini akan menjadi pangsa pasar yang menggiurkan. Selain itu, tingkat konsumsi masyarakat indonesia sangat tinggi bahkan tertingi nomor satu di dunia. Maka tidak ada pasar yang paling potensial melebihi Indonesia. Selanjutnya, tinggal bagaimana masyarakat Indonesia mengelolanya.

Untuk menumbuhkembangkan potensi bisnis halal di Indonesia, dibutuhkan beberapa strategi sebagai upaya akselerasi optimalisasi, diantaranya; 1). Harus ada peran maksimal dan campur tangan pemerintah. 2). Undang-undang Nomor 33 /2014 tentang Jaminan Produk Halal (UU JPH) harus bisa menjadi alat yang bisa meng-engineer perubahan. 3). Adanya pengembangan SDM dan industri halal yang kuat. 4). Menjadikan sertifikasi halal sebagai bagian dari exellent service. 


\section{REFERENSI}

Afroniyati, Lies, 2014. "Analisis Ekonomi Politik Sertifikasi Halal Oleh Majelis Ulama Indonesia”. JKAP (Jurnal Kebijakan dan Administrasi Publik). Vol 18 (1): 37-52. https://doi.org/10.22146/jkap.6870

Lukihardianti, Arie, 2017. "Industri Makanan Bersertifikat Halal Masih Minim di Jabar." $\quad$ Republika, $21 \quad$ September http://nasional.republika.co.id/berita/nasional/daerah/17/09/21/owlws 1384industri-makanan-bersertifikat-halal-masih-minim-di-jabar

Badan Pusat Statistik, 2010. "Sensus Penduduk 2010; Penduduk Menurut Wilayah dan Agama yang Dianut," www.bps.go.id, https://sp2010.bps.go.id/index.php/site/tabel?tid=321.

Dirjen Bimas Islam Kemenag RI, Persentase Produk Yang Beredar Dan Produk Bersertifikat Halal, diakses Kamis, 19 April 2019, http://simbi.kemenag.go.id/halal/assets/collections/newsletter/files/55642c827e6 ac.pdf

Evans AD, Evans S. 2012. Halal Market Dynamic: An Analysis. London (UK): Imarat Consultants.

Faqiatul, MW \& Anissa HP, 2018. "Model Pengembangan Industri Halal Food di Indonesia." Jurnal Muqtasid. Vol. 9(1): 1-13

Faridah, HD, 2019. "Sertifikasi Halal Di Indonesia: Sejarah, Perkembangan, Dan Implementasi." Journal of Halal Product and Research. Vol. 2(2): 68-78.

Handoyo, 2016. "Potensi Besar Dari Bisnis Halal.” https://nasional.kontan.co.id/news/ potensi-besar-dari-bisnis-halal

Kementerian Perencanaan Pembangunan Nasional/ Badan Perencanaan Pembangunan Nasional, 2018. Masterplan Ekonomi Syariah Indonesia 2019-2024: Hasil Kajian Analisis Ekonomi Syariah di Indonesia. Jakarta: Kementerian Perencanaan Pembangunan Nasional/ Badan Perencanaan Pembangunan Nasional

Keputusan Menteri Agama Republik Indonesia Nomor 982 Tahun 2019 Tentang Layanan Sertifikasi Halal

Kusnadi, Moh. 2019. "Problematika Penerapan Undang-Undang Jaminan Produk Halal Di Indonesia”, Islamika: Jurnal Keislaman dan Ilmu Pendidikan, Vol. 1 (2): 116132

Larasati, Ananya, dkk. (2019). "Pengaruh Label Halal Terhadap Produk Kecantikan.” AlMaal: Journal of Islamic Economics and Banking. Vol. 1(1): 48-64. http://dx.doi.org/10.31000/almaal.v1i1.1815

LPPOM MUI, (2008). Panduan Umum Sistem Jaminan Halal LPPOM MUI. Jakarta: Lembaga Pengkajian Pangan Obat-Obatan Dan Kosmetika Majelis Ulama Indonesia. 
LPPOM MUI, 2019. "Data Statistik Produk Halal LPPOM MUI Indonesia 2012-2019." https://www.halalmui.org/mui14/main/page/data-statistik-produk-halal-lppommui-indonesia-2012-2019

Nasrullah, Aan. 2018. “Analisis Potensi Industri Halal Bagi Pelaku Usaha Di Indonesia." Jurnal At-Tahdzib. Vol.6(1): 50-78

Prabowo, Sulistyo dan Azmawani Abd Rahman, 2016. "Sertifikasi Halal Sektor Industri Pengolahan Hasil Pertanian," Forum Penelitian Agro Ekonomi. Vol. 34 (1): 5770.

Purnomo, Dwi, 2011. Strategi Pengembangan Agroindustri Halal Dalam Mengantisipasi Bisnis Halal Global, Disertasi Institut Pertanian Bogor.

Putra, Panji Adam Agus, 2017. "Kedudukan Sertifikasi Halal Dalam Sistem Hukum Nasional Sebagai Upaya Perlindungan Konsumen Dalam Hukum Islam," Amwaluna: Jurnal Ekonomi dan Keuangan Syariah. Vol.1(1): 150-165.

Sari, Desi Indah, 2018. "Perlindungan Hukum Atas Label Halal Produk Pangan Menurut Undang-Undang." Repertorium: Jurnal Ilmiah Hukum Kenotariatan. Vol. 7(1): $1-14$

Shahbandeh, M. 2019. "Top Five Global Muslim Consumer Food Expenditure 2017 By Country." https://www.statista.com/statistics/737162/global-muslim-food-andbeverage-market/

Sumarsongko. 2013. "Penerapan Sistem Jaminan Halal Untuk Mendapatkan PAH yang ASUH.” Presentasi Direktur LPPOM MUI Kaltim dalam Rakorwil IV MUI; 2013 Nov 6; Samarinda, Indonesia.

Thomson Reuters, 2018. State of the Global Islamic Economy Report 2017/2018. Dubai The Capital of Islamic Economy.

Warta Ekspor, 2015. Jurnal Kementrian Perdagangan Republik Indonesia. Ditjen PEN/WRT/56/VII/2015. 